\author{
Review Article \\ www.ijrap.net (ISSN:2229-3566)
}

\title{
PANCHAKARMA IN SWASTHA: A REVIEW
}

Manal VM *1, Shreyas D M ${ }^{2}$, Kiran M Goud ${ }^{3}$

${ }^{1}$ PG Scholar, Department of Panchakarma, Sri Kalabyraveshwara Swamy Ayurvedic Medical College, Hospital and Research Center, Bengaluru, Karnataka, India

${ }^{2}$ Assistant Professor, Department of Panchakarma, Sri Kalabyraveshwara Swamy Ayurvedic Medical College, Hospital and Research Center, Bengaluru, Karnataka, India

${ }^{3}$ Professor and Principal, Department of Panchakarma, Sri Kalabyraveshwara Swamy Ayurvedic Medical College, Hospital and Research Center, Bengaluru, Karnataka, India

Received on: 01/02/21 Accepted on: 15/03/21

\author{
*Corresponding author \\ E-mail: manalshajil@gmail.com
}

DOI: $10.7897 / 2277-4343.120257$

\begin{abstract}
Ayurveda is an ancient science of life since time immemorial. Ayurveda, apart from providing various therapeutic measures for diseases, emphasizes on maintenance, promotion of health and prevention of diseases through diet and lifestyle regimens. According to the seasons, their dosha will get vitiated in the body which may additionally in flip leads to many diseases. If one takes care of this by performing Shodhana in each season may additionally pacify the vitiated dosha and help in preventing the ailment, these will act as preservative, promotive, and curative. This article enlightens on maintenance of preventing the occurrence of diseases by following Panchakarma for Rasayanadi asadharana guna prapti.
\end{abstract}

Keywords: Panchakarma, Shodhana, Preventive.

\section{INTRODUCTION}

Ayurveda has rightly emphasized Swastha as the normalcy of activity of Dosha, Dhatu, Agni and Mala. It also includes Prasanna, Atma, Indriya, and Manas. This explanation is similar to the definition of WHO i.e., Health is a state of complete physical, mental, social and spiritual wellbeing of a person and not merely the absence of disease ${ }^{1}$. To achieve the same, Ayurveda advocated Dinacharya, Ritucharya etc. where Panchakarma pays a vital role.

Panchakarma presents a unique approach to Ayurveda with specially designed five procedures of internal purification of body through nearest possible route. Such purification allows the biological system to return to homeostasis and to rejuvenate rapidly and also facilitates the designed pharmacotherapeutic effects of medicines administered which in turn bring about homeostasis of body humors, eliminates the disease-causing complexes from the body and check the reoccurrence and progression of disease. Hence, all the efforts to be made to clear out malas or doshas at appropriate time. The five techniques of Panchakarma includes Vamana Karma (therapeutic emesis), Virechana Karma (therapeutic purgation), Asthapana Basti (Therapeutic decoction enema), Anuvasana Basti (therapeutic oil enema) and Nasya Karma (nasal medication).

Panchakarma is carried out under

- Panchakarma in Swastha i.e., in Dinacharya and Ritucharya.

- Roganusara Panchakarma

- Panchakarma for Rasayanadi asadharana guna prapti

\section{Definition of Swastha}

Srushtu nirvikarathvena thishtathi ethi swasthaha².
The condition where the body is devoid of any abnormality is known as Swastha.

Samadosha samagnishcha samadhatu malakriya Prasannatmaendriya manaha swasthaityabidhiyate ${ }^{3}$

The Bio- humors (dosha), Tissues (Dhatu) and metabolic waste products (Mala) must be in equilibrium and the digestive strength brought to be in normal stage followed through Healthy Soul and Calm mind and energetic Sense organs is stated to be in Swastha (Health).

The equilibrium state of dosha is known as health and disequilibrium between the doshas leads to illness.

\section{Panchakarma in Health}

The aim of Ayurveda is "Swasthasya swasthya rakshanam aturasya vikara prashamanam ${ }^{4}$ "

To maintain the health of a healthy person and to cure the disease of the diseased ones.

Prevention is considered one of the prime aims of Ayurveda. Ayurveda believes in the Pancha mahabhuta Siddhant. It is believed that the internal milieu of the body changes daily as well as seasonally depends on the variation in environment. Different regimens are essential to maintain the equilibrium. In this regard, Dinacharya, Ritucharya and Vegadharana (Not suppressing the natural urges) are advised as mandatory ritual. Following of Panchakarma and daily regimens like Abhyanga, Vyayama, Kavala, Gandoosha Anjana, Pratimarsha nasya, Dhumapana etc., will prevent many diseases. Seasonal regimens include detoxification according to the seasons like in Vasant - Vamana, Sharad - Virechana and Raktamokshana and in Varsha - Basti 
(Niruha basti and Anuvasana) $)^{5}$ etc., Aggravated doshas are pacified by using Reduction therapy (Langhana), Digestion (Pachana) and palliative remedy (Shamana) but there might also be possibilities of recurrence. By adopting Bio purification therapy, the doshas get eliminated from its root, if once eliminated from the physique it won't reoccur, that is known as Apunarbhava chikitsa (radical treatment) ${ }^{6}$.

\section{Ritu Shodhana}

Kala (time) is all powerful, self-emerged and doesn't possess a beginning, middle and end. The changes occurring in the universe are bound to adhere to a definite mechanism governed by kala. Depending upon the necessity to study the effects of seasons and application of treatment modalities accordingly, a year is divided into 6 seasons where in each season comprises of 2 months. Shishiradi Ritus - For describing the manifestation of rasas, understanding strength of the individual based on seasonal effects, adopting Ritucharya. Pravrutaadi Ritus - For administration of Panchakarma i.e., Ritu shodhana for Swastha in order to prevent the disease as well as promotion of health. Ritucharya to avoid complications of Chaya and Prakopa of doshas according to ritu. Hence panchakarma mentioned in Ritucharya helps in prevention of disease.

Table 1: Stages of dosha in different ritu

\begin{tabular}{|c|c|c|c|}
\hline Ritu & Sanchaya & Prakopa & Prasara \\
\hline Hemanta & - & - & Pitta \\
\hline Shishira & Kapha & - & - \\
\hline Vasanta & & Kapha & \\
\hline Grishma & Vata & - & Kapha \\
\hline Varsha & Pitta & Vata & \\
\hline Sharad & - & Pitta & Vata $^{7}$ \\
\hline
\end{tabular}

Doshas, which is accumulated, will be pacified automatically without influence of any treatment. This concept of self conciliation is called as Ritu - Kriyakala. Whenever an individual indulges in ahara and vihara which provoke a particular dosha may produce respective disorders. So shodhana becomes mandatory choice in order to eliminate the same.

To prevent the occurrence of endogenous diseases, maintenance of tissue elements in homeostasis, one must undergo ${ }^{8}-$

- Vamana in Chaitra Masa i.e. later half of Vasanta ritu.

- Virechana in Margashirsha Masa i.e. later half of Sharad ritu.

- Anuvasana and Niruha Basti in Shravana Masa i.e., later half of Praavruta ritu.

The doshas undergoing increase slowly, in the body of such persons, who are negligent of taking purificatory measures, produce many diseases quickly which might even defy treatment. ${ }^{9}$

The accumulation of doshas arising from cold season should be expelled out during Vasanta; that arising from the Grishma should be expelled during abhrakaala i.e., (rainy reason); that arising from varsha be expelled during ghanaatyaya (autumn) expeditiously and effectively. By this people will not become victims of diseases born by the effect of seasons. Such aggravated doshas in different seasons should be counteracted by applying appropriate ways. One, who lives according to Ritucharya, never suffers from severe disorders caused by seasonal factors. Therefore, ritu shodhana in appropriate seasons helps to expel Sanchita malas.

\section{Ritucharya from Brihatrayee}

Six ritu are mentioned in Brihatrayee and lifestyle in each Ritu is explained with reason of Chaya (accumulation), Prakopa (vitiation), Prashama (pacifying) of doshas. Along with lifestyle Shodhana and allied procedures are also prescribed to prevent forthcoming seasonal diseases.

Table 2: Ritucharya from Brihatrayee

\begin{tabular}{|c|c|c|c|c|c|}
\hline Ritu & Month $1^{10}$ & Dosha $^{11}$ & Charaka $^{12}$ & Susrutha $^{13}$ & Ashtanga hrudaya ${ }^{14}$ \\
\hline Shishira & Magha/ Phalguna & Chaya of kapha & $\begin{array}{c}\text { Abhyanga, Utsadana } \\
\text { Murdhii taila, Jentaka atapa sweda }\end{array}$ & Avagaha Swedana & Swedana, Udvartana \\
\hline Vasanta & Chaitra/Vaisakha & Prakopa of Kapha & $\begin{array}{c}\text { Vamana, Udvartana, } \\
\text { Dhumapana, Kavala, Anjana }\end{array}$ & $\begin{array}{c}\text { Utsadana, } \\
\text { Shirovirechana } \\
\text { Vamana, Niruha }\end{array}$ & $\begin{array}{l}\text { Vamana, Udvartana, } \\
\text { Nasya, Gandoosha }\end{array}$ \\
\hline Grishma & Jyeshta / Ashadha & Chaya of vata & Sheetopachara & Sheetopachara & Sheetopachara \\
\hline Varsha & $\begin{array}{c}\text { Shravana / } \\
\text { Bhadrapada }\end{array}$ & $\begin{array}{l}\text { Prakopa of Vata, } \\
\text { Chaya of Pitta }\end{array}$ & Udvartana, Gharshana & Niruha & Asthapana \\
\hline Sharad & Ashwin / Karthik & Prakopa of Pitta & $\begin{array}{l}\text { Snehapana, Virechana, } \\
\text { Raktamokshana }\end{array}$ & $\begin{array}{c}\text { Virechana, } \\
\text { Raktamokshana, } \\
\text { Snehapana } \\
\end{array}$ & $\begin{array}{c}\text { Virechana, } \\
\text { Raktamokshana, } \\
\text { Snehapana } \\
\end{array}$ \\
\hline Hemant & $\begin{array}{l}\text { Margashirsha/ } \\
\text { Pausha }\end{array}$ & & Abhyanga, Utsadana, Murdha taila & Avagaha Swedana & Swedana, Udvartana \\
\hline
\end{tabular}

Table 3: Vegavrodhijanya lakshanas

\begin{tabular}{|l|c|}
\hline \multicolumn{1}{|c|}{ Vega } & Panchakarma \\
\hline 1. Mutra vega & Avagaha sweda, Abhyanga, Avapidaka Nasya, Bastikarma \\
\hline 2. Purisha vega & Sweda, Abhyanga, Avagaha, Basti, Virechana \\
\hline 3. Vata vega & Snehana, Swedana, Varti, Basti, Anulomana, Virechana \\
\hline 4. Shukra vega & Abhyanga, Avagaha, Sweda, Basti \\
\hline 5. Chardi vega & Vamana, Virechana, Raktamokshana, Taila abhyanga \\
\hline 6. Udgara vega & Snehana, Swedana, Vamana, Virechana \\
\hline 7. Kshavathu vega & Abhyanga, sweda, Navana nasya, Ghritapana \\
\hline 8. Jrimbha vega & Abhyanga, Sweda, Navana nasya, Vataghna aushadhi \\
\hline 9. Nidra vega & Taila Mardana, Nidra ${ }^{15}$ \\
\hline
\end{tabular}




\section{Rasayana - Vajikarana and Panchakarma}

Having ascertained that the koshta is purified of all impurities, rasayana - Vajikarana therapy should be administered. Rasayana drugs due to their inherent antioxidant and antitoxic properties possibly act at subcellular level, attributed to act directly on dhatus. Rasayana helps not only in preventing early aging but also in preventing the occurrence of diseases by promoting the Ojus.

"Na avishudha shareerasya yukto rasayano vidhihi

$\mathrm{Na}$ baati vaasasi klishte rangyoga evahithaha"16

Sushruta acharya has quoted that if srotas are not clean then Rasayana effect will not be achieved to the maximum extent just as an unclean cloth does not take up the colour.

\section{"Bhudhi prasadam balam indriyanaam dhatu sthirathvam jvalanasya deepthim \\ Chirrath cha pakam vayasaha karothi samshodhanam samyak upasya manam"17}

Shodhana helps in the proper attainment of Rasayana effect by strotoshodhana and provides Buddhi, Indriya prasadam, Balam, Indriya dhatu sthiratvam etc. This leads to delayed process of ageing.

\section{DISCUSSION}

"Malapaham roga haram balavarna prasadanam

Peetvasamshodhanam samyakayusho yunjyate chiram"18

If Shodhana administered properly it expels out the vitiated doshas, pacifies the diseases, increase the strength and varna of the person.

Acharyas defined that in each and every person's body according to Seasons, Food, Regimens and behavior there will be accumulation, aggravation and spreading of humor which vitiates and causes diseases therefore almost all Acharyas have mentioned about following the Daily regimens and Seasonal bio purification.

Acharya Vagbhata has discussed exclusive types of Panchakarma together with adjuvant therapies in Ritu adhyaya. These are additionally names as Swasthya Panchakarma, means a healthy individual can undergo special Shodhana as preventive and maintenance of an individual Chakrapani on Charaka Samhita explained Swastha Chatushka and guided about maintenance of the health of a person and prevent diseases,

\section{CONCLUSION}

Being healthy means balance and equilibrium in all the physiological activities of the body and mind. This harmonious situation gives pleasure and eternal happiness devoid of stress. All this can be achieved if one follows Dina charya and Ritu charya. Those who do not follow a course of life conducive to the maintenance of health are susceptible to above mentioned and some other diseases. A physician advised to make all perform such functions which bring forth and maintain health. A man always becomes healthy only when he properly follows Dina charya, Ritu charya or else become diseased. Chaya, Prakopa and Prasara of the dosha in accordance with Ritu are normal. This may aggravate the precise dosha which may additionally lead to diseases. For the same, conducting specific Shodhana according to Dosha: like Vasanta ritu - Vamana, Sharad ritu - Virechana, Varsha ritu - Basti chikitsa may additionally stop the disease.
Seasonal shodhana in this context is not only foremost Shodhana, the majority are upakramas like Abhyanga, Kavala, Gandoosha, Padaghata, Lepa they additionally pacify the aggravated and vitiated doshas.

\section{REFERENCES}

1. http://www.who.int/about/who-we-are/frequently-askedquestions.

2. Agnivesha, Charaka Samhita with Ayurveda Dipika commentary, Sutra Sthana 5:21, Reprint edition, Chaukhambha Orientalia; 2015. p. 76.

3. Agnivesha, Charaka Samhita with Ayurveda Dipika commentary, Sutra Sthana, 5:41, Reprint edition, Chaukhambha Orientalia; 2015. p. 179.

4. Vagbhata, Ashtanga Hridaya with Arundatta and Hemadri commentary, Chikitsa Sthana, 1:4, Reprint edition, Chaukhambha Surbharati Prakashana; 2014. p. 7.

5. Agnivesha, Charaka Samhita with Ayurveda Dipika commentary, Sutra Sthana 16:22, Reprint edition, Chaukhambha Orientalia; 2015. p. 76.

6. Agnivesha, Charaka Samhita with Ayurveda Dipika commentary, Sutra Sthana 16:22, Reprint edition, Chaukhambha Orientalia; 2015. p. 77.

7. Vagbhata, Ashtanga Hridaya with Arundatta and Hemadri commentary, Chikitsa Sthana, 14:8, Reprint edition, Chaukhambha Surbharati Prakashana; 2014. p. 820.

8. Vriddha Vagbhata, Ashtanga Sangraha with Arundatta, Hemadri and Sashilekha Sanskrit commentary, Sutra sthana, 4:23, Reprint edition, Chaukhambha Sanskrit Sansthan; 2016. p. 33 .

9. Agnivesha, Charaka Samhita with Ayurveda Dipika commentary, Siddhi Sthana 6:4, Reprint edition, Chaukhambha Orientalia; 2015. p. 802.

10. Vagbhata, Ashtanga Hridaya with Arundatta and Hemadri commentary, Chikitsa Sthana, 12:24, Reprint edition, Chaukhambha Surbharati Prakashana; 2014. p. 574.

11. Agnivesha, Charaka Samhita with Ayurveda Dipika commentary, Sutra Sthana 6:7, Reprint edition, Chaukhambha Orientalia; 2015. p. 44.

12. Sushruta, Sushruta Samhita with Nibandha Sangraha, Nyayachandrika commentary, Sutra Sthana 6:12, Reprint Edition, Chaukhambha Sanskrit Sansthan; 2017. p. 60.

13. Vagbhata, Ashtanga Hridaya with Arundatta and Hemadri commentary, Sutra Sthana, 3:18-22, Reprint edition, Chaukhambha Surbharati Prakashana; 2014. p. 163.

14. Agnivesha, Charaka Samhita with Ayurveda Dipika commentary, Sutra Sthana 7:46, Reprint edition, Chaukhambha Orientalia; 2015. p. 107.

15. Vagbhata, Ashtanga Hridaya with Arundatta and Hemadri commentary, Sutra Sthana, 4:8, Reprint edition, Chaukhambha Surbharati Prakashana; 2014. p.164.

16. Sushruta, Sushruta Samhita with Nibandha Sangraha, Nyayachandrika commentary, Chikitsa Sthana 27:4, Reprint Edition, Chaukhambha Sanskrit Sansthan; 2017. p. 494.

17. Vagbhata, Ashtanga Hridaya with Arundatta and Hemadri commentary, Chikitsa Sthana, 16:60, Reprint edition, Chaukhambha Surbharati Prakashana; 2014. p. 734.

18. Agnivesha, Charaka Samhita with Ayurveda Dipika commentary, Sutra Sthana 17:22, Reprint edition, Chaukhambha Orientalia; 2015. p. 222.

\section{Cite this article as:}

Manal VM et al. Panchakarma in Swastha: A Review. Int. J. Res. Ayurveda Pharm. 2021;12(2):107-109 http://dx.doi.org/10.7897/ $\underline{2277-4343.120257}$ 